\title{
Economic aspects of production of Caiman crocodilus yacare
}

\author{
LAURA B.T. CARREIRA ${ }^{1}$ and OMAR J. SABBAG ${ }^{2}$ \\ ${ }^{1}$ Departamento de Zoologia, Universidade Estadual Paulista “Júlio de Mesquita Filho", \\ Avenida 24-A, 1515, Bairro Bela Vista, 13506-900 Rio Claro, SP, Brasil \\ ${ }^{2}$ Departamento de Fitotecnia, Tecnologia de Alimentos e Sócio-Economia, Universidade Estadual Paulista \\ "Júlio de Mesquita Filho", Avenida Brasil, 5, Centro, 15385-000 Ilha Solteira, SP, Brasil \\ Manuscript received on July 12, 2013; accepted for publication on June 4, 2014
}

\begin{abstract}
The breeding of crocodilians is still a recent activity in Brazil. Its peak was in the 1990's, but it has gaps in its production, as there are no norms for the commercial breeding of these animals in captivity. However, its economic potential is great, and the search for ecological balance and viability of commercial production has become a challenge among farmers of this activity. Therefor, the objective of the study was to economically analyze the production of Caiman crocodilus yacare on a farm located in Caceres, state of Mato Grosso, identifying relevant items of costs in the activity, as well as the parameters related to the profitability and viability of the activity. The economic results for the breeding of this animal were positive, with profitability ratios higher than $70 \%$.
\end{abstract}

Key words: Caiman crocodilus yacare, costs, economic viability, herpetology, fitability.

\section{INTRODUCTION}

The breeding of Caiman crocodilus yacare is a recent activity in Brazil, reaching its peak in the 90s. Since then, this activity has aimed to constantly improve its potential for production of meat and leather, in addition to reducing pressure on native stocks, thus preventing the extinction of these animals.

However, due to planning mistakes of breeding, lack of market research and flaws in the nutritional management of the animals, there was a decline in the level of acceptance of the product by the market, especially the leather, as well as a drastic reduction in the number of breeders and captive animals at the end of that decade.

Correspondence to: Laura Borelli Thomaz Carreira

E-mail: laurabtcarreira@gmail.com
The economic potential of breeding alligator is huge due to the use of the urine (fixative in perfumery), flesh and skin. Thus, breeding systems in development aim to optimize the product range that is more promising, currently the skin, whose production is estimated in produced skin area. In turn, the skin area at any age of the live alligator can be determined or estimated by the abdominal circumference of animals. Thus, one can also assume the yield of meat before slaughter and predict the optimal time of slaughter of the animal, based on the track or equilibrium of the "costbenefit curves" according to the breeding system adopted (Rieder et al. 2004). For many years, the skin of Caiman crocodilus yacare, illegally hunted, was responsible for supplying approximately $75 \%$ 
of the international market for crocodilian skins, a total that ranged from 1 to 1.5 million skins a year.

One of the main advantages of studying the feasibility of management systems for conservation and economic use (or conservation through economic use) of crocodilians is that there are examples of its extreme in terms of intensification (ie, hunting and breeding in captivity) as well as its intermediate version (ie, creating offspring from eggs collected in the wild). Moreover, these systems have received names, internationally recognized, respectively: "harvest", "farming" and "ranching" (Hutton and Webb 1992).

To achieve success in a business, you need to make it give a sufficient economic outcome to cover all expenses incurred, remunerate the investiment and generate enough profit to reinvest in the activity as well as to adapt to changes in economic reality. With the evolution of technology and the quest for acquiring better quality products, farmers need to develop more techniques in both the production area, and the financial management of their property (Segala and Silva 2007).

In this sense, the rural entrepreneur must decide how use their funds in productive activity through a comprehensive analysis in order to verify the viability of their investment. Hence the need for a survey of the economic and financial viability of the enterprise in question.

Because it is a breeding of high cost, with a high feed cost due to the diet of the animals being essentially protein, this study aimed to economically analyze the production of Caiman crocodilus yacare on a property located in Caceres, state of Mato Grosso, to identify relevant items pertinent to the activity, as well as the parameters related to the profitability and viability of the activity, the key factors for sustainability in the activity.

According to Piran (2010), there is no record of breeding wild animals in captivity before 1950. Thus, the understanding is that all skins of crocodiles that fueled the market until 1960 were obtained from animals captured from nature.
Still according to Piran (2010), the illegal exploitation of crocodiles was not driven solely by marketing the animal's skin, since their meat had been sold long before. The state of Amazonas, for example, was considered the largest producer of illegal alligator meat in the world, with the main markets being the state of Pará in Brazil and Colombia.

Farming systems received the following designations: harvest or extensive management (removal of individuals from a population without it entering into decline, thus seeking to establish a biologically sustainable and economically viable exploitation rate), farming or intensive management (production and reproduction of a species in captivity in a closed cycle) and ranching or semi-intensive management (collection of eggs in nature and subsequent "fattening" of pups in captivity) (Verdade 2004).

According to Coutinho (2002), the most conservative estimates show that only the fur market represent about US\$ 200 million per year. Still according to the author, several factors determine the success of management systems, among which:

i) the biological factors, such as the management form, the features of the species managed and the environmental variability; ii) the logistical factors such as equipment, processing and product clearing; iii) the economic factors, such as communication with the development of the agribusiness of skins and leathers of wild species in the market and the product commercialization; iv) regulatory factors and mechanisms of supervision and encouragement.

From the economic perspective, as advocated by Noronha et al. (1995), a Project of capital investment is any productive activity which involves the mobilization of some financial resources in the form of productive assets, hoping to generate resources from future production, assuming the possibility of monetary quantification of inputs and outputs associated with the project. 
According to Hoffmann et al. (1978), from the point of view of management, the most important objective of agricultural records in an agricultural enterprise is the financial evaluation and determination of their profits and losses over a given period, providing subsidies to diagnose the business situation and make an effective planning.

For Nogueira (2004), even more important than estimating and controlling costs is the producer make decisions based on the data collected. For that there are no correct and incorrect models, some are stricter and others less, but they should allow the producer to take managerial and operational decisions based on information on costs and cash flow. In this sense, Sabbag et. al. (2007) highlight the need for a management agent who prioritizes efficient management of production costs in order to maintain not only the viability of the agribusiness in concern, but also their survival.

\section{MATERIALS AND METHODS}

The study was conducted in a cooperative of breeders of alligators, in the municipality of Cáceres, state of Mato Grosso, during the months of January and February 2011. On that property the breeding system adopted is the ranching, or semi-intensive management, which consists of collecting eggs / hatchlings from nature, authorized by IBAMA (Brazilian Institute of Environment and Renewable Natural Resources).

To obtain the animals, the Brazilian Institute of Environment and Renewable Resources (IBAMA) demands that these be collected from farms which are accredited in the IBAMA; in the municipality there are six properties that are authorized by this agency, but they must comply with the following procedure: first the cooperative hires IBAMA so that it carries out an annual survey of potential breeding population, thus calculating a probable number of eggs at each spawning, and authorizing the collection of a percentage by the property, which will subsequently be bred in captivity until slaughter.
After the visit a single license for the collection and transportation is issued by the following government agencies of the Ministry of Environment (MMA), Brazilian Institute of Environment and Renewable Natural Resources (IBAMA) and the State Superintendence of Mato Grosso (SUPES / MT) which have the power to issue such license.

There is also a description of the work areas where the collections of the material are performed. The areas for collection and for procedure execution are described within the collect points. It also includes the number of nests (with maximum average of eggs and hatchling), scientific name and common name of the species that will be collected.

The studied property has a total area of 12 hectares, containing four circular experimental tanks for hatchlings, 11 barns with 64 stalls of 2 x $2 \mathrm{~m}$ each, four tanks with dimensions of $15 \times 9.5$ $\mathrm{m}$ each, in addition to the industrial sector which comprises na area of $497.33 \mathrm{~m} 2$ contained in the total area previously mentioned, where are located the slaughter house, boning ... are located. In the period evaluated the property had about 30,000 animals of the species Caiman crocodilus yacare.

To calculate the cost of production, the operational cost structure of production used by the Agricultural Economics Institute (AEI), proposed by Matsunaga et al. (1976) was adopted. The operating cost consists of the following items: manual operations, materials and depreciation. In operations that reflect the production system, we calculated the materials consumed and the time required for machinery and manpower to perform each operation, defining in these two cases, the technical coefficients in terms of man/day.

Operating expenses were calculated based on the following items:

\section{A) MANUAL Operations}

The entire production process is done by manual labor including, as major activities, the supply 
and preparation of animal diets, cleaning and maintenance of the barns, preslaughter/slaughter, boning, packaging and shipping. These were developed over a period of 8 hours/day, and were merged as follows: activities related to preslaughter/ slaughter and skin cleaning were performed on the same day, while activities related boning, packaging, shipping, supply and preparation of animal diets, cleaning and maintenance of barns, were held the next day in order to conciliate the activities performed by company employees, due to its limited number of available labor.

\section{B) MATERIALS}

Spending on materials referred to the cost of ingredients for feed preparation, equipment for refrigeration, visceral grinding equipment, equipment for washing live alligators, equipment for containing live animals, etc. These expenditures were obtained by the quantity of materials used and their respective unit prices.

The "skip a day" food supply system was used, resulting in approximately 15 treatments per month to feed 30,000 animals, considering a consumption of $10 \%$ of body weight per animal.

\section{C) DEPRECIATION OF MACHINERY / EQUIPMENT}

Depreciation was calculated on the straight-line method, proportional to the life span for each device.

The profitability indicators used in the study are considered by Martin et al. (1997): Gross Revenue (GR), obtained by multiplying production by the average price paid to producers; Operating Profit (OP), resulting from the difference between Gross revenue and total costs, to this indicator, measures the profitability of the activity in a short term, showing the financial and operational conditions of the farming activity and Profitability Index (PI), representing the proportion of gross income which constitutes resources available after coverage of total costs.
Still, for the analysis of the economic viability of the investment, a cash flow was drawn up, reflecting the values of the inputs and outputs of resources and products, and determining the Internal Rate of Return (IRR) which, by definition, is one that makes the net present value of zero, and is calculated as follows:

$$
\sum \underset{\mathrm{t}=0}{\mathrm{n}}(1+\rho)^{-\mathrm{t}}=0
$$

where $\boldsymbol{\rho}$ is the Internal Rate of Return (IRR), Lt are the net cash flows and $\mathbf{t}$ are the production periods of culture ranging from zero to $\mathbf{n}$ (Noronha 1981).

Other indicators used to analyze the economic feasibility of creating alligators were: NPV (net present value), the Period of Recovery Capital (Pay Back Period) establishing the time needed to recover the investment and the ratio $\mathrm{B} / \mathrm{C}$ (benefit/ cost) for the activity.

One of the most accepted principles of the financial theory is that the goal of financial management should be to maximize shareholder wealth. This pre-concept and the implication that shareholder wealth is measured by NPV is often cited as a justification for the criterion of NPV in estimate capital applied (Ross 1995).

The commonly accepted definition of NPV in the literature is the present value of all cash flows (assuming equity financing) discounted at the weighted cost of the firm capital that is used (Woods and Randall 1989).

The cost-benefit analysis has been an appropriate tool to evaluate proposals for public projects since the middle of last century. The theoretical tools are well established, to measure and compare the economic well-being (Campbell and Brown 2005).

\section{RESULTS AND DISCUSSION}

Our initial hypothesis was that it was a costly activity, mainly because of the protein diet of the animals, and the difficult dealing with animals 
they do not consider as domestic animals. Yet, even with all these obstacles in breeding, it was possible to diagnose a positive outcome in their revenue.

Investments are considered as all costs of capital goods, which in the future will be transformed into benefits (Padoveze 1997).

The initial investment at time zero was U\$ $614,513.23$, plus the reinvestment that occurred over the time horizon of 15 years (acquisition of new products over production cycles, which added U\$180,532.26), of which the construction of warehouse / purchase of tanks (33.3\%) with hooks and reels (30\%) accounted for items of higher acquisition as fixed capital in the activity.

With respect to production costs, it resulted in U\$ 246,591.16/year, considering that the labor represented in $48 \%$ and the energy $27.7 \%$ of total costs, enhancing rationality in the manual operations of the cultivation system to maximize the efficient use of productive resources. Regarding depreciation (U\$ 18,597.89), this is not a real monetary disbursement for the producer, but must be computed, as it registered depreciation of equipment used among the costs of the various financial years.

To analyze the profitability of the production system, some inferences are exposed to result in gross revenue. Initially, the property holds three weekly slaughters of 180 animals each, between 3-4 years of age and 4-7 $\mathrm{kg}$ because this is the point considered by the property as the balance between the skin quality and carcass yield. The hot carcass of an animal weighs about $3 \mathrm{~kg}$. The prime cuts, tail fillet, dorsum fillet, sirloin steak and fillet mignon, cost about U\$23.95/Kg, whereas the other cuts as chips and fish fingers cost on average U\$20.95/Kg and alligator sausage costs U\$10.78 / Kg.

Regarding the production of skin, these are classified by centimeter, where every centimeter of first line skin, i.e. without any kind of damage, is equivalent to U\$4.19 and its measurement is done by measuring the abdominal diameter of the animals.
Then an animal with a $30 \mathrm{~cm}$ abdominal diameter has a skin worth U\$125.75. However a second line skin, i.e. which has some kind of damage will cost U\$2.99 /centimeter. Thus, a 30$\mathrm{cm}$ skin will have a value of U\$89.82. Still, there is a second classification of alligator skins by type of cut, they are: Belly Cut or Dorsal Cut and Hornback Cut (HB) or ventral. The type of cut is defined by customer request and do not interfere in the price of the raw material.

It is noteworthy that the sales price quote for meat and leather products was performed during the analysis of the property, resulting in a value of U\$ 934,131.74/year, considering all products produced by the property in question and respecting the characteristics described above.

The operating profit, calculated as the difference between gross revenues and total costs was U\$ $687,540.58$. The profitability index (PI), which indicates the proportion of gross income which constitutes profit after covering costs, resulted in $73.6 \%$, which means that the alligator production system is extremely profitable. In this regard, it is noteworthy that the profitability obtained was more expressive compared to other operating systems, such as corn $(21.81 \%)$ and dairy cattle $(11.07 \%)$, research indicated by Machado (2001) and Silva (2001). It is worth noting that these results are established from the 4th year of production, where operating expenses are effective between 1 and 3 years in the production system.

With such information, through a cash flow / annual cycle, the main parameters of viability were analyzed, as shown in Table I. The cash flow is shown by the difference between the inflows and outflows in cash over time, for a horizon of 15 years of the project.

It is observed by the results that the activity is viable, in those circumstances where the project was evaluated from the 6th year, the NPV becomes positive (which in practice translates into the $3 \mathrm{rd}$ year from the initial income of the activity), with a return of $114 \%$ for the farmer and an $11.17 \%$ IRR. 
TABLE I

Indicators of feasibility of Caiman crocodilus yacare breeding on a property located in the city of Cáceres, state of Mato Grosso, Brazil.

\begin{tabular}{ccccccc}
\hline Year & $\begin{array}{c}\text { Operational } \\
\text { expenses }\end{array}$ & Revenues & Liquid flow & NPV & B/C & IRR \\
\hline & & & $-614,513.23$ & & \\
1 & $246,591.16$ & - & $-246,591.16$ & $-847,146.40$ & $-0,40$ \\
2 & $246,591.16$ & - & $-246,591.16$ & $-106,661.65$ & $-0,80$ \\
3 & $246,591.16$ & - & $-246,591.16$ & $-1,273,654.34$ & $-1,20$ \\
4 & $246,591.16$ & $934,131.74$ & $411,700.95$ & $-729,057.80$ & $-0,08$ \\
5 & $252,946.22$ & $934,131.74$ & $681,185.51$ & $-220,036.35$ & 1,03 & $11,17 \%$ \\
6 & $246,591.16$ & $934,131.74$ & $687,540.58$ & $264,652.63$ & 2,14 & \\
7 & $246,591.16$ & $934,131.74$ & $687,540.58$ & $721,906.38$ & 3,26 \\
8 & $246,591.16$ & $934,131.74$ & $687,540.58$ & $1,153,277.84$ & 4,38 \\
9 & $246,591.16$ & $934,131.74$ & $687,540.58$ & $1,560,232.06$ & 5,50 & \\
10 & $414,413.29$ & $934,131.74$ & $519,718.45$ & $1,850,440.126$ & 6,34 \\
11 & $246,591.16$ & $934,131.74$ & $687,540.58$ & $2,212,627.93$ & 7,74 \\
12 & $246,591.16$ & $934,131.74$ & $687,540.58$ & $2,554,314.53$ & 8,58 \\
13 & $246,591.16$ & $934,131.74$ & $687,540.58$ & $2,876,660.40$ & 9,70 & 10,82 \\
14 & $246,591.16$ & $934,131.74$ & $687,540.58$ & $3,180,760.25$ & 11,94 & $28,37 \%$ \\
15 & $252,946.22$ & $934,131.74$ & $681,185.51$ & $3,464,995.17$ & \\
\hline
\end{tabular}

Dollar value for the period from 03 Jan to 20 Feb 2011 was R\$ 1,67 (mean of February 2011). Source: Research data.

According to Sanches et al. (2006), Internal Rate of Return (IRR) can be considered as the interest rate received for an investment over a given period, in regular intervals, in which payments are made to cover all expenses for the breeding and revenues from product sales (cash flow). This study showed an IRR greater than the interest rate that could be received by the owner, if they chose to invest their capital in a more secure financial application, for example, the Selic rate (Special System of Clearance and Custody), indicating that the activity is feasible under the conditions in which it was analyzed.

Still according to Kreuz et al. (2008), while the minimum attractiveness rate remains lower than the IRR, becomes more feasible to invest in the activity than in leaving the money applied at the minimum attractiveness rate. Given the above results for the producer in question, security in the decision to undertake the production of alligators in the medium term is understandable, demonstrating an IRR greater than the cost of capital. Faro (1979) also proposes that it is possible to calculate the payback period on the capital invested by the IRR and the cash flow.
Thus the payback (PB) activity was calculated in two steps:

1) Simple Payback (SPB): only the period of the accumulated balance of the cash flow without the incidence of interest rate, which in this case was $6 \%$ per annum, resulting in a period of 4 years and 11.7 months for obtaining return on invested capital it was considered.

2) Economic Payback (EPB): in this case, to strengthen the real scenario of the monetary update over a planning horizon, the period of the accumulated balance of the cash flow and the incidence of interest rates, which in this case was $6 \%$ p.a., resulting in a period of 5 years and 5.4 months for obtaining return on invested capital it was considered.

As shown in Table II, the analyzed property could lose up to a maximum of $5 \%$ of their average annual revenues to remain positive in its NPV, in order not to hinder its productivity when evaluated, considering the same capital cost of the activity (6\% p.a.). 
TABLE II

Sensitivity analysis for variation in average annual revenues of breeding Caiman crocodilus yacare on a property located in the city of Cáceres, state of Mato Grosso, Brazil.

\begin{tabular}{|c|c|c|c|c|c|c|c|}
\hline & $100 \%$ & $95 \%$ & $90 \%$ & $85 \%$ & $80 \%$ & $75 \%$ & $70 \%$ \\
\hline $\begin{array}{c}\text { Variation in } \\
\text { average annual } \\
\text { revenues }\end{array}$ & U\$934,131.7 & U\$887,425.1 & U\$840,718.6 & U\$794,012.00 & U\$747,305.4 & U\$700,598.8 & U\$653,892.2 \\
\hline Rate i & $6 \%$ & $6 \%$ & $6 \%$ & $6 \%$ & $6 \%$ & $6 \%$ & $6 \%$ \\
\hline $\begin{array}{c}\text { Simple Pay } \\
\text { Back (Years) }\end{array}$ & 5 & 5 & 5 & 5 & 5 & 6 & 6 \\
\hline $\begin{array}{c}\text { Economic Pay } \\
\text { Back (years) }\end{array}$ & 5 & 5 & 6 & 6 & 6 & 7 & 7 \\
\hline NPV & U\$173,200.8 & U\$68,376.6 & -U\$36,447.6 & -U\$141,271.8 & -U\$246,095.9 & -U\$350,920.1 & -U\$455,744.3 \\
\hline IRR & $9 \%$ & $7 \%$ & $5 \%$ & $3 \%$ & $0,54 \%$ & $-2,08 \%$ & $-4,94 \%$ \\
\hline $\mathrm{B} / \mathrm{C}$ & 1,96 & 1,73 & 1,50 & 1,28 & 1,05 & 0,82 & 0,59 \\
\hline
\end{tabular}

Dollar value for the period from 03 Jan to 20 Feb 2011 was R\$ 1,67 (mean of February 2011). Source: Research data.

The following factors fall as potential barriers and causative of deficit in average annual revenues: a) Seasonality of production: time where animal production may decline due to diseases, temperature changes, irregularity in the diet, among others, b) Problems with input suppliers, which may cause decrease in production if there is a failure to provide these for numerous factor, such as lack of products to be purchased in the market, lack of capital for the acquisition of the same, difficulty negotiating with suppliers and c) lack of demand: in this case the producer can stock products (meat and skin) temporarily, since they are perishable. Therefor, in the long-term absence of demand by the consumers, producers may be unable to sell and therefore do not get enough revenue to maintain its production.

Therefore, as claimed by Sabbag et al. (2007), good zootechnical production management is necessary to complement an economic evaluation in order to maximize production and ensure its survival, highlighting, in particular, the purpose of mitigating undesirable variations of planned data.

\section{CONCLUSIONS}

Through the use of the key economic parameters, it was possible to quantify the production of a breeding unit of alligators, which allowed us to evaluate the profitability in the activity.

Thus, the economic results for the breeding of Caiman crocodilus yacare were positive in the unit evaluated for short-term analysis, with profitability ratios higher than $70 \%$, mainly due to the appreciation and diversification of its exotic products to consumers.

On the other hand, costs must be related to the technical management of the ctivity, considering the rationalization of production factors, such as labor and supplies, contributing to a lower operating cost. In a horizon of several cycles, the results are also attractive, with an IRR greater than the cost of capital for a horizon from the 6th year.

Now the sensitivity analysis showed, under the conditions studied, a loss of up to $5 \%$ of its average annual revenues. In this context, the activity maintains its positive NPV, not incurring losses the economic outcome of its productivity. In short, the quantification of the technical coefficients of production becomes essential rationalizing costs for a management process in the sector.

\section{RESUMO}

A criação de crocodilianos ainda é uma atividade recente no Brasil. Tendo seu ápice na década de 1990, possui 
lacunas em sua produção, já que não existem normas próprias para a criação comercial em cativeiro destes animais. Contudo, seu potencial econômico é grande e a busca pelo equilíbrio ecológico e a viabilidade da produção comercial tem se tornado um desafio entre os produtores rurais desta atividade. Dessa forma, o objetivo do presente trabalho foi analisar economicamente a produção de Caiman crocodilus yacare em uma propriedade situada em Cáceres/MT, identificando os itens relevantes dos custos na atividade, bem como os parâmetros relacionados à rentabilidade e viabilidade da atividade. Os resultados econômicos para a criação deste animal foram positivos para uma análise de curto prazo, apresentando índices de lucratividade superiores a 70\%, sobretudo em função da valorização e diversificação de seus produtos exóticos para o mercado.

Palavras-chave: Caiman crocodilus yacare, custos, viabilidade econômica, herpetologia, rentabilidade.

\section{REFERENCES}

CAMPBELl HF AND BROWN RP. 2005. A multiple account framework for cost-benefit analysis. Eval Program Plann 28(1): 23-32.

Coutinho M. 2002. Desenvolvimento do agronegócio de peles e couros de espécies silvestres. Reuniões técnicas sobre couros e peles. Embrapa Gado de Corte. Documentos: 127.

FARO C. 1979. Elementos de engenharia econômica. Atlas.

HofFman R, Engler JC, SERrano O, Thame AM AND NeVES E. 1978. Administração da empresa agrícola. São Paulo: Ed. Pioneira Econômica, 325.

Hutton J And WeBB G. 1992. An introduction to the farming of crocodilians. Directory of Crocodilian Farming Operations 2: 1-39.

Kreuz CL, Souza A And Clemente A. 2008. Custos de produção, expectativas de retorno e de riscos do agronegócio mel no planalto norte de santa catarina. Custose @gronegócio on line 4(1).

MACHADO AC. 2001. Análise econômica de recria e engorda de bovinos na região de Itajá-GO. Congresso Brasileiro de Administração Rural, Goiânia.

Martin N, Serra R, Oliveira M, ÂNGelo J AND OKaWa H. 1997. Sistema custagri: sistema integrado de custos agropecuários. São Paulo: IEA/SAA, p. 1-75.
Matsunaga M, Bemelmans P And Toledo P. 1976 Metodologia de custo de produção utilizada pelo iea. Agricultura em São Paulo 23(1): 123-139.

NoGUEIRA MP. 2004. Gestão de custos e avaliação de resultados: agricultura e pecuária. Scot Consultoria.

Noronha J, DUARTE L AND AIDAR A. 1995. Avaliação de projetos de investimentos na empresa agropecuária. Aidar, ACK Administração Rural. São Paulo: Paulicéia, p. 213-251.

NORONHA JF. 1981. Projetos agropecuários: administração financeira, orçamentação e avaliação econômica. Fundação Estudos Agrários Luiz de Queiroz.

PADOVEZE CL. 1997. Contabilidade gerencial: um enfoque em sistema de informação contábil. Atlas.

PIRAN C. 2010. Propostas para a gestão da qualidade e da segurança do alimento da unidade processadora de carne de jacaré da coocrijapan. Biblioteca Digital de Teses e Dissertações da Universidade Federal de São Carlos.

Rieder A, De Melo EAS, Borges MF, De CÁssia R, Borges P, IGNÁCIO ÁRA AND CAMACHO AC. 2004. Relações biométricas de jacarés (caiman crocodilus yacare) criados em sistema de cativeiro, cáceres, alto pantanal, mato grosso, brasil. IV Simpósio sobre recursos naturais e sócio-econômicos do Pantanal-SIMPAN.

Ross SA. 1995. Uses, abuses, and alternatives to the netpresent-value rule. Financial Management 24(3): 96-102.

SABbag OJ, Dos ReIS Rozales R, TARsitano MAA AND SILVEIRA AN. 2007. Análise econômica da produção de tilápias (oreochromis niloticus) em um modelo de propriedade associativista em ilha solteira/sp. Custos e @ gronegócio on line 3(2).

SAnches EG, Henriques MB, Fagundes L And Silva AA. 2006. Viabilidade econômica do cultivo da garoupaverdadeira (epinephelus marginatus) em tanques rede, região sudeste do brasil. Informações Econômicas 36(8): $15-25$.

SEgAla CZS AND SILVA IT. 2007. Apuração dos custos na produção de leite em uma propriedade rural do município de irani-sc. Custos e @gronegócio on line 3(1).

SILVA EC. 2001. Análise econômica da cultura do estudo de níveis e épocas de aplicação de nitrogênio na cultura do milho no sistema de plantio direto em solos de cerrado. Congresso Brasileiro de Administração Rural, Goiânia.

VERDADE LM. 2004. A exploração da fauna silvestre no Brasil: jacarés, sistemas e recursos humanos. Biota neotrópica, Campinas, v. 4, nº 2, p. 1-12. Disponível em: $<$ http://www.biotaneotropica.org.br/v4n2/es/fullpaper? bn02804022004+pt>. Acesso em: 13 jan. 2015.

WoODS JC AND RANDALL MR. 1989. The net present value of future investment opportunities: its impact on shareholder wealth and implications for capital budgeting theory. Financial Management 18(2): 85-92. 